
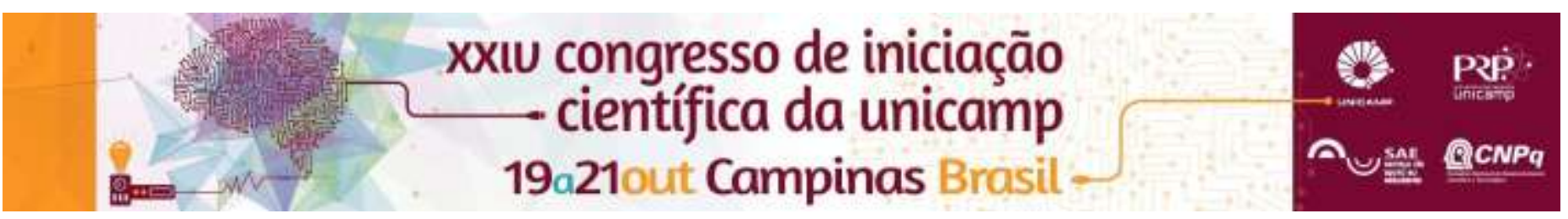

\title{
Estudo da influência dos tratamentos térmicos de recristalização e envelhecimento sobre as propriedades mecânicas de ligas Ti- $\beta$ metaestáveis
}

\author{
Joana Furlan Gaiotti *, Luiz Gustavo Santos, Rodrigo José Contieri \\ Resumo
}

Recentemente, a demanda por materiais com elevada razão entre resistência mecânica e peso resultou no uso mais intenso de ligas de titânio do tipo $\beta$ metaestáveis. A fase $\beta$ em ligas de titânio apresenta baixa resistência mecânica e baixo módulo de elasticidade. Entretanto, tal comportamento mecânico pode ser drasticamente alterado por meio da implementação de novas rotas de processamento, assim como, pela aplicação de tratamentos térmicos de envelhecimento. Pretende-se avaliar os efeitos da deformação e de tratamentos térmicos de recristalização nas propriedades mecânicas das ligas do tipo $\beta$ metaestáveis: TIMETAL 21S (Ti-15Mo-3Nb-3Al-0.2Si), e suas variações com adições de Cr, Ti-13Mo-3Nb-3Al-0.2Si-1,6Cr e Ti-13Mo-3Nb-3Al-0.2Si-3,2Cr.

\section{Palavras-chave:}

Titânio e sua ligas, deformação, dureza e difração de raios $X$.

\section{Introdução}

Em comparação com os principais materiais metálicos estruturais, as ligas de titânio exibem o melhor desempenho entre resistência mecânica e densidade com o aumento da temperatura de trabalho. A resistência mecânica das ligas de titânio apresenta valores semelhantes a de aços de alta resistência. Ainda comparado ao aço, o módulo de elasticidade do titânio puro é duas vezes menor que esse material. Recentemente, a necessidade de materiais com elevada resistência mecânica aliada a reduzido peso resultou no desenvolvimento de ligas de diversas composições, em particular, da liga TIMETAL 21S, de composição Ti-15Mo3Nb-3Al-0.2Si (\% em peso), que oferece, além das características inerentes as ligas de titânio, boa conformabilidade a frio, melhor resistência à oxidação, resistência a temperaturas elevadas e alta estabilidade térmica.

\section{Resultados e Discussão}

A preparação das ligas de titânio do tipo $\beta$ metaestáveis TIMETAL 21S, e suas variações com adições de $\mathrm{Cr}$ (conforme tabela 1) foram realizadas em forno de fusão a arco-voltáico com atmosfera controlada, em cadinho de cobre refrigerado através de fluxo de água. Após a preparação dos lingotes, parte dos mesmos foi cortada para posterior caracterização microestrutural e a outra parte reservada para processos subsequentes de laminação a frio.

Tabela 1. Composições selecionadas (\% em peso)

\begin{tabular}{|l|l|l|l|l|l|}
\hline Liga & $\mathrm{Mo}$ & $\mathrm{Nb}$ & $\mathrm{Al}$ & $\mathrm{Cr}$ & $\mathrm{Si}$ \\
\hline 01-TIMETAL 21S(L1) & 15 & 3 & 3 & 0 & 0,2 \\
\hline 02-TIMETAL 21S_mod1(L2) & 13 & 3 & 3 & 1,6 & 0,2 \\
\hline 03-TIMETAL 21S_mod2(L3) & 11 & 3 & 3 & 3,2 & 0,2 \\
\hline
\end{tabular}

As ligas foram submetidas a tratamentos térmicos de homogeneização composicional à temperatura de $1000 \stackrel{\circ}{C}$ durante 8 horas. Esse tratamento permitiu a total eliminação de heterogeneidades resultantes da fusão a arco, como por exemplo do tipo composicional ou de tamanho de grãos. Logo, após a finalização deste tratamento térmico, os lingotes seguiram para a etapa posterior de conformação plástica.

Inicialmente, as amostras laminadas foram cortadas e embutidas a frio em resina de baquelite, sendo na sequencia lixadas e polidas. Finalizada a parte metalográfica, que devido à inexperiência tomou mais tempo do que previsto, as amostras foram caracterizadas por microscopia ótica. Detalhes das microestruturas podem ser observados na figura 1.

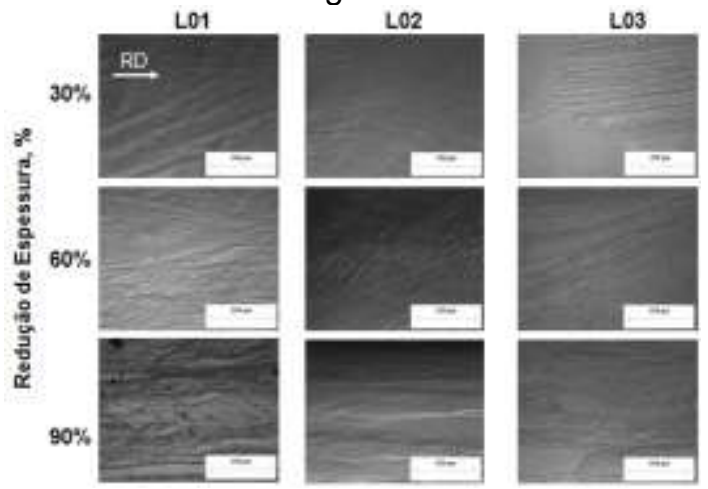

Figura 1. Microestrutura das amostras da ligas L1,L2 e L3 (tabela 1) deformadas a frio.

Adicionalmente, ensaios de difração de raios- $X$ foram realizados com as amostras solubilizadas e deformadas. A figura 2 apresenta detalhes dessas analises. Percebe-se que, para as três ligas estudadas, antes e após a deformação, foi encontrada apenas a fase de beta do titânio (estrutura CCC). O resultado é condizente com o esperado uma vez que a fase Omega (hexagonal) é de ordem namométrica com fração volumétrica baixa, sendo impossível sua detecção por DRX.

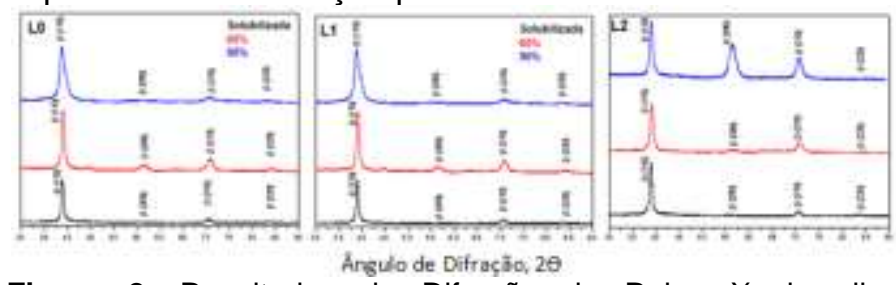

Figura 2. Resultados de Difração de Raios $X$ das ligas estudadas.

\section{Conclusão}

Conclui-se que a adição de $\mathrm{Cr}$ influencia fortemente os mecanismos de deformação e nas medidas de dureza sem interferir nas transformações de fases.

\section{Agradecimentos}

Conselho Nacional de Desenvolvimento Científico e Tecnológico (CNPq) 